\title{
Mourning the Old World whilst Building the New? A Rejoinder
}

Leah Bassel and Akwugo Emejulu

With their focus on mourning, amnesia and counter-hegemony on shifting terrain in Britain, Gargi Bhattacharyya and Kim Allen have addressed the spirit of our book and added their own. Nicole Grégoire and Alexandra Kelbert offer us a different perspective informed by a long history of Afrofeminist activism on the European continent. We take this opportunity to express our heartfelt thanks and also to go further, collectively, in reflecting on the task behind us - as much as any piece of writing can be - and that which lies ahead. To do this we ask three questions.

\section{Who remembers and how should we remember?}

We have broken new ground with our book, Minority Women and Austerity: Survival and Resistance in France and Britain, by trying to capture the experiences of minority women who are systematically erased but nevertheless resist during this ongoing moment of political and economic instability generated by the 2008 economic crisis. As we emphasise in the book and continue to do here, these destabilising processes that undercut minority women's economic security and public politics are in no way 'new' and must be consistently and relentless historicised. Our commentators have responded to the question of 'history' and 'time' in interesting ways that give us food for thought. Allen notes the importance of our 'historically-attendant frame' to avoid, as Bhattacharyya argues elsewhere, remaking the world 'before austerity' through nostalgia (2015: 3). Both Kelbert and Grégoire emphasise the need to memorialise and undertake historically-informed research that reflects the diversity and difference between different minority women and the lasting legacy of Afrofeminist activism in Europe. As Kelbert argues: 'There is a particular form of epistemological violence that lands heavily on minority women, whereby our stories of resistance are erased...instead of recognising this moment as a new iteration of a longstanding Black radical tradition...our ancestral ties to those who came before us are cut, in search for a sexy narrative of self-made, ahistorical, privatised subjects' (p.5).

For Bhattacharyya, the book demonstrates 'the last gasp of the black voluntary sector' and, for her, brings a lament for the old activist world that is passing. '[It is] the geography that emerges through the fragile accommodations reached between racialized communities and the quickly receding forces of welfare capitalism, that is fading away.' The space of the political is thus remade. The construction of the post-war welfare states and their attendant welfare settlements, we think, should rightly be mourned-to a certain extent. The making of social citizenship is the story of the $20^{\text {th }}$ century-and its unmaking is the story of the $21^{\text {st }}$ century. The Marshallian idea of positive rights-the right to welfare, housing and a decent wage-are fading from view.

However, the concept and practices of European social citizenship have not and cannot accommodate the experiences and demands of people of colour-and women of colour in particular. As Fiona Williams $(1995 ; 1999)$ has long argued, the welfare settlements were made on the backs of women which codified a public/private divide between men and women, privatised women's care work and consigned people of colour to second class social citizenship. We mourn this old world in which rights (for some groups) were an important part of the public vernacular and which supported, to limited degree, women of colour's on- 
going redistribution and recognition struggles. However, it would be ahistorical to mourn the liberal democratic order which does not and cannot see women of colour as political agents-much less as fully human. We must take Gloria Wekker (2016), Barnor Hesse (2007) and Charles Mills (1997) seriously. The construction of European modernity requires a despised Other: the Muslim woman, the migrant woman, the Black woman. What, truly, can be mourned under these conditions?

To these reflections we add the spaces in which these histories of inequalities and resistances have played out. Kelbert and Grégorie remind us of the consistent failures of the old liberal order-particularly in Francophone Europe-in which minority women cannot be seen as political agents and authors of their lives. Indeed, the heavy ideological weight and hegemonic whiteness of the difference-blind French Republic offers clarity to our mourning. The multiculturalism which we may or may not mourn the loss of in Britain is swiftly condemned by some French groups as tokenistic and an extension of the same colonial logic that unveils, incarcerates and deports. There is no linearity 'from multiculturalism' to rely on when we leave the British Isles. Britain may well have a fading language of multiculturalism and all its accoutrements of statistics and toothless public bodies, but as we have shown in our book, minority women are still fighting remarkably similar battles of basic recognition and survival on both sides of the English Channel. As Grégoire notes: 'in officially "multiculturalist" countries, minority women's intersectional claims can be as much silenced as in "assimilationist" ones where ethnic and racial minority groups are not recognised as legitimate political agents' (p.3). This uprooting is essential to see the broader patterns of erasure, and political racelessness, that form the landscape of minority women's (im)possible activism. These are not 'models' or 'cases'. They are fields of discipline that minority women subvert and reject.

\section{Who speaks?}

We share Bhattacharyya's disappointment that this book is necessary, as a corrective to minority women's absences in accounts of austerity and resistances to it. However, this 'corrective' should not be so readily dismissed since, as Kelbert notes, 'the language of antiracism and the discourse of political racelessness are used to shut out the voices of Black and minority women...the book gives minority women the space to be experts in their own fields, when expertise is all too often precisely what is denied to minority women, including in the field of activism' (p.2-3). Telling counter-hegemonic stories is a crucial practice of Black feminist politics, especially since 10 years after the start of the economic crisis, accounts of minority women's political behaviour under austerity are still frustratingly rare. As the Combahee River Collective (1977) argued more than 40 years ago:

This may seem so obvious as to sound simplistic, but it is apparent that no other ostensibly progressive movement has ever considered our specific oppression as a priority or worked seriously for the ending of that oppression...We realize that the only people who care enough about us to work consistently for our liberation are us.

This struggle over who speaks and on behalf of whom is, for us, an essential component of minority women's public politics and it can never be taken for granted that other scholars will do this work. 
Further, our book is less about illuminating the workings of austerity and its asymmetrical effects, though this is essential. First and foremost, we study minority women's activism, who gets to be an activist and what counts as activism. Certainly, it is through the experiences explored in the book that austerity is revealed and understood. But our focus is primarily on activism, rather than the exegesis of austerity.

We start with experiences as a source of knowledge rather than a means of comparing to the past and mourning the loss of its fragile accommodations. We insist on the power of these narratives not just to show us the retractions and elimination of entitlement but also the spaces to act. The question Bhattacharyya asks of whether 'race-naming can illuminate the workings of austerity' (p.2) is, always, secondary to the question of who acts and is recognised as acting. How do they/we respond to the stripping of entitlement from every sphere of life, beyond identifying its loss? The answer: minority women's activism challenges not just austerity, but also the norms of intelligibility through which minority women are (selectively) heard. These forms of activism breach the existing order and enact equality rather than waiting for it to be bestowed (Bassel 2017). We work in the spirit of a 'politics of listening' through this book and our ongoing work. This enables us, in turn, to push further the question: 'who acts and who is recognised as acting?'

\section{Who acts?}

Allen, Grégorie and Kelber all identify the need to undertake 'forms of counter-hegemonic action....which challenges the violence of austerity and exposes its asymmetrical effects' (Allen, p.2). One of the inevitable shortcomings of our book is that our fieldwork took place before many new feminist activists were mobilised to action. We went to press right in the middle of important actions various groups such as Black Lives Matter UK, Sisters Uncut and Mwasi Collectif were organising.

For these reasons, Akwugo is undertaking a new research project, The Politics of Catastrophe, which picks up where our book leaves off and explores how women of colour (note the change in nomenclature-this project is interested particularly in how different kinds of racialised women build solidarity between themselves and others) are organising against austerity, against the far right and for migrants' rights in England, the Netherlands and the United States. What is striking about the preliminary findings of this work is how, despite the flourishing of radical activism in response to the tripartite catastrophes of austerity, the rise of the far right and the mainstreaming of extremist language and policies, the pattern of women of colour's political behaviour remains the same. As we noted in our book and as Akwugo has found in her new project, before women of colour activists can fight for the issues that they care about, they must first struggle to be seen and heard as legitimate political agents. In all three countries, the activists must fight for recognition amongst social movement allies which they experience as exhausting and dispiriting labour (Emejulu and van der Scheer forthcoming). Despite these conditions, we see creative organising which has at its heart, the care and protection of the despised and disrespected Other-the very same Other that European modernity requires for its existence as we discussed above. In mapping the new frontiers of women of colour's activism we see its foundation as an ethic of radical care that elevates everyday survival as revolutionary (Emejulu and Bassel forthcoming). Radical care for Others, in turn, is used as the 
prefigurative foundation for destroying the unloved old world and building the new in which caring for and about Others is at its heart.

In our future work we will be mapping the cross-border networks and collaborations across the European continent to which Kelbert rightly points and, which Grégoire reminds us, are at the same time deeply embedded in local histories and self-understandings. We take seriously Grégoire's critique of avoiding homogenising women of colour's perspectives and experiences by being attentive to localised actions and conditions. We are particularly interested in the maintenance of these new networks over time, often founded on carebased survival strategies as radical action. As Grégoire notes, these actions take place outside of white Left spaces and the third sector. How will this politics of survival itself survive, given multiplying hostilities and shifting terrain?

Recent developments urgently require further enquiry, especially the troubling links between the economic crisis, the Mediterranean crisis and the rise of the "hostile environment' policies in the UK that Kelbert discusses. These policies have further entrenched hierarchies of 'deserving' and 'undeserving', both opposing and entangling 'the poor' and migrants in Brexit Britain and across Europe (Anderson 2013; Demir 2017). We have witnessed the ways in which minority women have led the charge in challenging these policies. While the policies and crises are 'new', much of the song remains the same. We celebrate the notable victories won through the passionate and powerful leadership of women of colour at the forefront of campaigns such as Schools Against Border Controls and Docs not Cops that have forced the Home Office to reverse its directive of compelling schools and hospitals to collect immigration data from pupils and patients. Yet this fire is sometimes burning out through lack of resources and fatigue (not helped by the division of labour in refugee welcome and solidarity movements across Europe structured along racialised and gendered lines dogged by accusations of white saviourism (Emejulu and van der Scheer forthcoming) or are (almost) extinguished through 'innocent' attempts to incorporate them in white Left spaces which can refuse to acknowledge women of colour's leadership and agency.

\section{Conclusions}

Since writing our book, the economic and social conditions of women of colour have further eroded. This constitutes a catastrophe and should be treated as such by scholars and policymakers. However, contained within every crisis are the seeds of resistance and we are now witnessing a flourishing of Black feminist, Afrofeminist and women of colour feminist activism across the European continent. Despite the very real obstacles they face, women of colour do not have the luxury of pessimism or inaction. Instead, we see creative and innovative activism which insists on women of colour's humanity and agency to build a new world.

\section{Bibliography}

Anderson, B. (2013). Us and Them?: The Dangerous Politics of Immigration Control. Oxford: OUP. 
Bassel, L. (2017). The Politics of Listening: Possibilities and Challenges for Democratic Life. London: Palgrave.

Bhattacharyya, G. (2015). Crisis, austerity and everyday life: Living in a time of diminishing expectations. Basingstoke: Palgrave Macmillan.

Combahee River Collective (1997 [1977]). 'A Black feminist statement', in Nicholson, Linda, The second wave: a reader in feminist theory, New York: Routledge, pp. 63-70

Demir, I. (2017). 'Brexit as a backlash against "loss of privilege" and multiculturalism' Discover Society 41: February.

https://discoversociety.org/2017/02/01/brexit-as-a-backlash-against-loss-of-privilege-andmulticulturalism/

Emejulu and Bassel (forthcoming 2018) 'Care and the Politics of Becoming', Journal of Common Market Studies Annual Review

Emejulu and van der Scheer forthcoming 'Care as Prefiguration'

Hesse, B. (2007) 'Racialized modernity: An analytics of white mythologies', Ethnic and Racial Studies, 30, 4, 643-63.

Mills, C.W. (1997) The Racial Contract. Ithaca: Cornell University Press.

Wekker, G. (2016) White innocence: Paradoxes of colonialism and race. Durham: Duke University Press.

Williams, F. (1999) Good-enough principles for welfare. Journal of Social Policy, 28(4), 667687.

Williams, F. (1995) Race/ethnicity, gender, and class in welfare states: A framework for comparative analysis. Social Politics: International Studies in Gender, State \& Society, 2(2):127-159. 